\title{
Development of Talking Chips Basic Learning Model in a Vocational High School (SMK) in Medan
}

\author{
Ana Rahmi, Siti Sutantie \\ Universitas Negeri Medan \\ anarahmi1963@gmail.com
}

\begin{abstract}
This study aims to describe how the application of Talking Chips learning model to improve motivation and learning outcomes of basic culinary art students of SMK Negeri 8 Medan. This research type is Research development. It consists of four stages, namely the stage of planning, development, implementation and reflection. The data collected in this research is students' motivation and basic culinary learning result. The results showed that the Talking Chips development model on basic caterers was validated by material experts and detain learning experts. From the validation results by two designers of learning, the assessment of $90.63 \%$ was obtained, while from the validation by two material experts, the assessment of $97.35 \%$ was obtained. 2) Based on the result of questionnaire of students' responses that have been done, the learning model of talking chips on the basic learning process gets $90.9 \%$ respondents stating that the learning model of chips attracts attention, increases interest in learning, motivates and looks interesting so that the learning model of talking chips is effectively used as a medium of learning on basic culinary art learning.
\end{abstract}

Keywords - conventional learning talking chips type, learning outcomes, basic culinary art

\section{INTRODUCTION}

Vocational educations have a very close relationship, have similarities and differences. The equation is equally equip the students with the competence that is in accordance with the world of work. The difference is at the level, the term vocational education is at the level of Vocational High School (SMK). While vocational education is at diploma or other higher education level that focuses on providing special skills to students. The orientation of vocational education is to provide competence that suits the needs of the World Business World. That is, vocational education, SMK, must have a close relationship with the World Business World Industry, the relationship can be useful for curriculum preparation, learning process, facilities to the evaluation of learning SMK. Including to provide industry insight and training for SMK teachers. Thus, the competencies given to the students, really fit the needs of the World Business World. Thus, SMK graduates who belong to the age of productive and have the competence, can be accepted in the world of work.

Vocational High School (SMK) is included in the type of formal education, as one of the institutions of secondary education, which aims to prepare students with the best in order to fill the needs of the business world and industry at this time and in the future. Vocational High School (SMK) is expected to educate and nurture students who produce graduates or skilled workers, professional and ready to work. Various steps to improve the quality of SMK was undertaken, among others, by raising the quality of Vocational High School(SMK).

Vocational High School (SMK) Negeri 8 Medan is an educational institution that manages Catering department, and has Basic Culinary subjects and Food Processing Technique subject matter. The result of observation that the problem that must be in search of solution is interest and motivation of student learning, if it is related to the data of value obtained from 34 students, who get value (100-90) as many as 9 students $(26.47 \%),(89-80)$ as many as 5 students $(14,7 \%)$, students who got enough score (79-75) as many as 5 students $(14,7 \%)$, and students who scored unfinished $(<75)$ as many as 15 students $44 \%$ ). Ideally, the school output gets decent work according to its competence and skill. However, the results of the schools have been less satisfactory due to the lack of graduate competency, which is characterized by the lack of graduate suitability and the needs of the industrial world.

In addition, teaching methods that are often used by teachers tend not to vet, whereas in conventional learning the classroom atmosphere tends to be teacher centered so that students become more passive and less motivated students in following the lesson. Teachers are less utilizing the learning model so that students are less interested in the subjects of food processing techniques, but also the media used is still not appropriate.Things that become factors causing low student learning outcomes can be seen in factors within the students themselves, such as interest, physiology, and motivation. Or factors from outside students such as learning media, facilities and infrastructure, learning resources and learning models (Dimyati and Mujiono, 2006). One effort to overcome the low learning outcomes of students on Basic culinary subjects required changes in the learning model. In addition teaching becomes centered on the process of continuing and mastery of the material. Students need to be trained to solve problems in order to succeed in learning.

Teachers should be able to encourage and train students to identify problems and solve them using their knowledge, but 
should also stimulate students to actively seek answers to their problems by using scientific procedures. This is where the professionalism of an absolute teacher as a provision of teaching and learning process. Teachers should be able to implement more student-centered learning or student center. Effective teaching skills are necessary to support the student center's learning. Cooperative learning model is not entirely new for teachers. Cooperative learning model is a model of learning that prioritizes the existence of groups, which can increase student activity, improve reasoning, logical thinking, active, creative, open, and curious. In addition, this model can improve interaction, increase student mastery of learning materials and will increase student motivation to be active in the learning process. One type of cooperative learning is talking chips, that is, students learn together in small groups and help each other. In this type each student is required to give advice, opinions, and ideas, even to answer the questions given by the teacher to each student. So researchers hope with Cooperative learning model is cooperative learning model type talking chips. In learning, there are often too dominant and talkative students in the group. Conversely, there is also a child who is passive and resigned to his partner who is more dominant. Type Talking Chips make students active and all students have equal opportunity to express their opinions. The use of Talking Chips type is intended to indicate the opportunity for each student in the group to contribute so that it is expected to increase student learning activeness (Lie, 2008).

\section{THEORETICAL STUDY}

The learning model is a teaching design that describes the process undertaken in the process to achieve specific changes in student behavior as expected (Wahab, 2009). Rusman (2009) argues that the learning model is a plan or pattern that is used as a guide in developing classroom learning or learning in tutorials and to determine learning tools including books, films, computers, curriculum and others. The learning model based on the view of constructivism is cooperative learning. According to Kagan (2000), cooperative learning is a term used in interactive learning procedures, where students learn together in small groups to solve problems.

Talking Chips cooperative learning model was first developed by Kagan in 1992. Lie (2008) suggests this model can be used in all subjects and for all ages of students. Cooperative type talk-type learners were first developed by Spencer Kagan in 1992. In the activities of talking chips, each group member gets an opportunity to provide their construction and listen to the views and thoughts of other members. Another advantage of this technique is to overcome barriers to equal opportunities that often color group work.

Excellence activities The Talking Chips type cooperative model is a learning model that can be used to overcome the equal opportunity barriers that often color the group work and ensure each student gets the same opportunity to participate and contribute to his or her own group.Learning is a major activity in education. Success or failure of achievement of educational goals depends on the learning process that occurs. According Hamalik (2010). Learning outcomes are a behavioral behavior of students that can be observed and measured in the form of knowledge change (Hamalik, 2012). Basic culinary materials are among other basic techniques of food processing is to process food with a variety of techniques. The basic techniques of food processing are divided into 2, namely, food processing techniques moist heat and dry heat cooking processing techniques. (Bartono, 2006).

By using cooperative learning model Talking Chips model, it is expected that students are more motivated and motivated to learn food processing technique. The key to the success of this learning model is concentration and cooperation. Every student is required to concentrate in understanding a material. In addition, students in groups are required to work with their group members. So that all members of the group able to his opinion with direction.

\section{METHOD}

Research and development research is carried out in Basic culinary art lesson, which is developing cooperative model of Talking Chips model through Dick \& Carrey learning model (2005). The preliminary study was conducted using a questionnaire of needs and literature review, on students and teachers. In the model test phase, the data collection technique used is the assessment of the results of the application of Talking Chips model to basic catering learning. The data collection instruments used in this study are: (1) questionnaire used to collect data at the preliminary study stage and development; (2) a questionnaire (assessment scale) is used to assess the outcome of the model implementation of basic culinary learning outcomes. The preliminary study was conducted analytically descriptively, to describe and analyze the Talking Chips model of Basic culinary art learning, mainly basic catering, learning methods, and evaluation, in developing the Talking Chips model.

The development strategy used is an adaptation of the development of learning model with multimedia Luther (Hadi, 2003), which is an effort to improve the quality of learning in the education environment. The steps of the development stage are as follows: Conduct preliminary research, which includes: (a) identification of learning needs and determining standards of competence; (b) do the learning analyst (c) identify the initial characteristics of the student; and d) writing basic competencies and indicators (e) writing benchmark reference tests, $(f)$ developing learning strategies embodied in syllabus and RPP related to; $(\mathrm{g})$ developing learning materials.

Collection of materials, which includes the collection of basic ingredients / materials. Develop a cooperative model of Talking Chips type includes: (a) opening instruction, (b) brief description, (c) basic competence (d) material description, (e) summary and bibliography, (f) feedback. Review and trial of Phase I, Phase II, Phase III. 


\section{RESULT AND DISCUSSION}

The results of the preliminary study are two, namely; needs analysis of the development of Talking Chips learning model; and Talking Chips model description. The teaching model developed from the Talking Chips learning model is characterized first, the involvement of students intellectually and emotionally in basic culinary learning, facilitated through the provision of opportunities for students to explore the basic culinary concepts learned and interpret the results of group exploration. This exploration allows students to interact with their own environment and experience, as a medium for constructing knowledge.

Second, students are encouraged to discover/construct their own basic culinary concepts that are being studied through interpretations done in various ways egg, discussing among group mates, or experimenting. In this way the concept is not transferred by the teacher, but is shaped by the students themselves based on experience and interaction with the environment that occurs when exploring and interpreting. In this way the student is encouraged to build on the meaning of his experience, so his understanding of the phenomenon being studied becomes increased. Third, students are given responsibilities in completing joint tasks through exploration activities, group interpretation. Another experience, here students get the opportunity to help friends in completing a task, a sense of togetherness and display of group work is an interaction arena that enriches the student experience.

So the learning model is successful if applied correctly a) Material; basic catering material adapted to be presented with the Talking Chips model is a material that demands a high understanding of the actual values, concepts or problems in society and the skills of applying such understanding in the form of real work. b). Learning Activities; learning with the Talking Chips model, divided into 6 sure phases 1) Delivering the goals and motivating the students, here the teacher conveys the learning objectives (or indicators of learning outcomes), the teacher motivates the students, the teacher associates the current lesson with the preceding one. 2) Presenting information, the teacher presents information to students by way of demonstration or by reading. 3) Organizing students into study groups, Teachers explain to students how to form learning groups, teachers organize students into study groups (each group consists of 4-5 people and must be heterogeneous, especially the gender and ability of students, and each member given the responsibility for studying or doing assignments), the teacher explains the use of the button medium as one of the tickets to argue within his or her own group. 4) Guiding group work and study, Teachers guide learning groups when students do the task. 5) Evaluation, Teachers evaluate learning outcomes about the material that has been learned or ask students to present their work, then proceed with discussion. 6) Giving rewards, Teachers reward outstanding students to reward students' efforts and learning outcomes both individually and in groups

On this occasion students are given the opportunity to express their opinions about the steps or ways of work, and how the assessment will be done and the expected results. Negotiations between teachers and students can occur, but at the end of the orientation it is expected to have an agreement. At the time of the teacher's core activity explains the basic culinary material. After explaining and the students understand the material, then the students sit into the group that has been distributed and the teacher explains the procedure implementation of learning models Talking Chips.

The result of the questionnaire of teachers' needs (100\%) states that the Talking Chips learning model has not been utilized in the basic culinary material. Questionnaire results of students' needs stated (52\%) states agree, model development model Talking Chips has not been too popular in basic culinary learning. Therefore it is necessary to develop a basic culinary Talking Chips model to improve learning activities. After obtaining the conclusion from the needs analysis, the next step is the collection of teaching materials. Collection of mate the analysis by the material expert on each aspect of the overall assessment is determined by the average score in each category. The results of the study were analyzed to determine the feasibility or not the development of the basic culinary Talking Chips learning model. Stage in this Talking Chips learning model, where the students are given the opportunity to know the basic catering related to their understanding, then the stage where the students together with the group can realize the learning that is more concrete and more involving them actively in basic culinary learning.

The learning design expert explained that the Talking Chips model evaluates the basic culinary based on three aspects: aspect of model stage $(85,23 \%)$, efficiency aspect $(87,7 \%)$, and model quality aspect, effectiveness $(88,75 \%)$. Overall these three aspects are in very good criteria $(89.58 \%)$.

TABLE I. ACQUISITION OF LEARNING MODEL LEARNING BASIC CULINARY TALKING CHIPS BY THE DESIGN OF LEARNING

\begin{tabular}{|l|c|c|}
\hline Indicator & percentage & criteria \\
\hline aspects of the model stage & 85,23 & Very good \\
\hline aspects of model quality & $87,7 \%$ & Very good \\
\hline $\begin{array}{l}\text { aspects of efficiency and } \\
\text { effectiveness }\end{array}$ & 88,75 & Very good \\
\hline
\end{tabular}

TABLE II. ACQUISITION OF DEVELOPMENT LEARNING MODEL BASIC CULINARY TALKING CHIPS BY EXPERT MATERIAL.

\begin{tabular}{|l|c|c|}
\hline Indicator & Percentage & category \\
\hline aspect of attraction & 75 & Good \\
\hline aspects of difficulty level & 74 & Good \\
\hline aspects of display quality & 76 & Good \\
\hline aspects of benefits & 71 & Good \\
\hline
\end{tabular}

The result of the percentage of product trial test according to the students are attractiveness aspect $(75.3 \%)$, difficulty level $(71 \%)$, and appearance aspect $(74 \%)$, and benefit aspect (76\%). Overall, the criteria agreed (74\%) percentage of product trials in Table 3 below. 
TABLE III. OBTAINING SCORE DEVELOPMENT OF LEARNING MODEL TALKING CULINARY BASIC PRODUCT TEST TRIAL.

\begin{tabular}{|l|c|c|}
\hline \multicolumn{1}{|c|}{ Indicator } & Percentage & category \\
\hline aspect of attraction & 75,3 & Good \\
\hline aspects of difficulty level & 71 & Good \\
\hline aspect of appearing & 74 & Good \\
\hline aspects of benefits & 76 & Good \\
\hline
\end{tabular}

The results of the percentage of student-based trials based on attractiveness aspects $(91.7 \%)$, aspects of difficulty $(89 \%)$, display aspect $(91.3 \%)$, and benefits $(91.4 \%)$. Overall in excellent criteria $(90.9 \%)$ percentage of trial usage in table 4 below.

TABLE IV. OBTAINING DEVELOPMENT SCORES LEARNING MODELS OF BASIC CULINARY TALK CHIPS DURING TRIAL USE.

\begin{tabular}{|l|c|c|}
\hline \multicolumn{1}{|c|}{ Indicator } & Percentage & category \\
\hline aspect of attraction & 91,7 & Very Good \\
\hline aspects of difficulty level & 90 & Very Good \\
\hline aspect of appearing & 90,8 & Very Good \\
\hline aspects of benefits & 91,5 & Very good \\
\hline
\end{tabular}

The results of the assessment of the development of the basic culinary teaching-learning model in general the value of responses from students assessed strongly agree, it is seen from product trials and trial usage increased from student responses. Percentage of Product Trials and Testing usage can be seen in table 5 below:

TABLE V. DIFFERENCE DIAGRAM OF PRODUCT TRIAL AND TRIAL USAGE

\begin{tabular}{|l|l|l|}
\hline Indicator & Percentage & category \\
\hline small group trial & 74 & Good \\
\hline large group trial & 90,9 & Very Good \\
\hline
\end{tabular}

The result of the next learning model development is validated by media experts and material experts. In the implementation, validation of media experts and material experts look at the learning model that has been developed, then the validator provides assessment, comments and suggestions of improvement related to the existing aspects in the sheet of validation of media experts and material experts. In some cases, researchers ask directly and discuss with the validator about matters relating to aspects that still require improvement so that the resulting product is really worthy of use for learning activities.

In the experimental design expert's validation results, it provides evaluation $(90.63 \%)$, that the learning model of talking chip is feasible to be used well and attracts the students' attention so as to create interactive learning. Then the material expert gives an assessment (97.35\%), that the basic culinary material is appropriate because the material is in accordance with the Curriculum, Syllabus, Learning Implementation Plan (RPP), Competency Standards (SK), Basic Competence (KD), Indicators and Learning Objectives.

The development of the talking chip model was revised in accordance with the suggestion of the instructional design expert and after being declared eligible, the product test was conducted (small group), and the (large group) trial of the talking chips model. From the experiment (small group), it is agreed that the developed talking chips model can be used in basic culinary learning, as well as in the experimental (large group) of basic culinary learning, which is strongly agreed to be used in the lesson.

Based on the above findings, concrete solutions are required through the application of Talking Chips learning models on basic culinary. With the implementation of this Talking Chips learning model, students are expected to obtain the principles of the experimental method that students like. This learning model of Talking Chips not only uses practicum methods in learning, but also allows students to plan activities and reflect what has been gained from basic practicum activities. Thus it is expected that basic culinary learning objectives that refers to the ultimate goal of basic culinary learning as a product that can improve attitudes and knowledge can be realized properly.

According to Clegg \& Berch (2001) at the end of each learning, students should be required to produce something so that what they have learned becomes meaningful, especially to solve problems that are often encountered in everyday life. As for the implementation of the learning model of talking chips each group member is assigned a number of cards or "chips" (usually two to three cards). Whenever one of the group members conveys an opinion in the discussion, one should put a card in the middle of the group. Each member is allowed to add his opinion until all the cards he has run out. If the cards he has run out, he should not talk again until all members of his group also spend all their cards. If all the cards have been exhausted, while the task has not been completed, the group may take the opportunity to divide the card again and the discussion can be resumed (Kagan, 2000).

Thus in the cooperative learning model Type Talking Chips: (1) students are divided into small groups of about 4-6 people groups. (2) The group of students is asked to discuss a subject matter or subject matter. (3) Each group is given 4-5 cards used for students to speak. After the student expresses his opinion, then the card is stored on the table of his group. The process continues until all students can use the card to speak. This method makes no students dominate and no students are not active, all students must express their opinions. In addition, the application of cooperative learning model of talking chips technique is a student oriented learning model, where this learning model corresponds to occupy a central position as the subject of learning through the activities of finding and finding the subject matter themselves.

Simply put, card use can be replaced by other small items that can attract students' attention, such as buttons, red beans, walnuts, pieces of straws, stalks, ice cream scoops, and others. Because the objects are jingling, the term for talking chips can also be called a "jingle button" (Lie, 2002). The jingle button activity requires grouping students into groups. This technique can contribute students equally. This technique can be used to discuss, listen to the views and thoughts of 
other members or to evaluate each other memorized. This is in line with Lie's statement that "in the jingling activity, each group member gets the same opportunity to contribute and listen to the views and thoughts of the other members. According to Sonia in "Talking Chips (A Book of Multiple Intelligence Exercise from Spain), Talking chips have two important processes, namely social processes and processes in the mastery of material.Social processes play an important role in talking chips that require students to work together in groups, so that students can build their knowledge within a social frame that is in the group. The students learn to discuss, summarize, clarify an idea, and the concept of the material they are learning, and can solve problems.

Model Talking Chips have a goal not only mastery of the subject matter, but the element of cooperation for mastery of the material. This is the hallmark of cooperative learning. In addition, talking chips are a method of learning in groups, then the group is a place to achieve the goal so that the group should be able to make students to learn. Thus all group members should help each other to achieve the learning objectives.In addition to the group, students can also interact

\section{REFERENCES}

[1] Abidin\&Yunus,

2014. DesainSistemPembelajarandalamKonteksKurikulum 2013. Jakarta: RefikaAditama.

[2] Achievement In Speaking Ability. Proceeding of the Fourth International Seminar on English Langguange and Teaching. ISBN: 978-602-74437-0-9: 62-67.

[3] Ahmadi, Abu \&WidodoSupriyono. 2008. PsikologiBelajar. Jakarta: RinekaCipta

[4] Andreas, J. \& Gabriel, J. 2010 Learning Mathematics With Understanding: A Cristical Consideration of The Learning Principle In The Principles and Standards for School Mathematics. The Montana Mathematics Enthusiast. 4 (1):103-114.

[5] Anggraini, V. D. 2013. Problem Based Learning, MotivasiBelajar, KemampuanAwal, danHasilBelajarSiswa SMK.

[6] Aravah, E. 2014. Teaching English to Large Multilevel Classes Majoring In Math, Biology and Chemistry by using 'Burst The Baloon' and Talking Chips' techniques. TEFLIN International Conference. 6 (1):1034-1038.

[7] Arikunto, Suharsimi. 2010. ProsedurPenelitianSuatuPendekatanPraktik.Jakarta: RinekaCipta.

[8] Arikunto, Suharsimi. 2012. Dasar-dasarEvaluasiPendidikan. Jakarta: BumiAksaras

[9] Djamarah, Syaful Bahri.2011.Psikologi Belajar. Jakarta: RinekaCipta

[10] Frianto.,Soetjipto, B.E., Amirudin, A. 2016. The Implementation of Cooperative Learning Model Team Game Taurnament and Fan-N-Pick To Enhance Motivation and Social Studies Learning Outcomes. IOSR Journal of Humanities and Social (IOSR-JHSS). 21 (5):27-42.

[11] Gilstrap, R. L. \& Martin. W. R. 1975. Current Strategies for Teacher, California, Santa Monica, Goodyear Publisher Company Inc.

[12] Golu W. 2005. StrategiBelajarMengajar. Jakarta : Grasindo

[13] Hamalik, Oemar. 2005. Proses BelajarMengajar. Jakarta: BumiAksara with other group members so as to create positive interdependence conditions within their classroom at the same time. The process of mastery of the material runs because the students are required to be able to master the material.

\section{CONCLUSION}

The research has drawn some conclusions, as follows: 1) in this development research using Talking Chips development model. This research develops instructional media based on orientation, exploration, interpretation, and recreation. The material on the learning media is the basic culinary material. From the result of validation by two media experts, obtained the assessment $(90.63 \%)$, while from the validation by two material experts, assessment (97.35\%). 2) Based on the results of the questionnaire of the responses of students who have done, cooperative learning model type talking chips on learning Basic culinary got a response $(90.9 \%)$ that the learning model of talking chips attract attention, increase interest in learning, motivate and looks interesting so that the media is expressed effectively used as a learning medium on basic culinary learning.

[14] Hariyanto,Y. 2015. PengaruhMetodePembelajaranTipe Talking Chips terhadapHasilBelajarSiswaPadaKompetensiDasarMemahami Model Atom Bahan Semi Konduktor di SMK Negeri 1 JetisMojokerto. JurnalPendidikanElektro, UniversitasNegeri Surabaya. 4 (3):999-1005.

[15] HilmaAstuti, 2013. Pengaruh Model PembelajaranKooperatifTipeKancingGemerincingTerhadapPembelajara nSejarahSiswaKelas XI IPS SMA Negeri 13 Banda Aceh. Skripsi (Unsyiah)

[16] Kagan, S. \& Kagan, M. 2009. Kagan Cooperative Learning. San Clemente: Kagan Publisher.

[17] Lie, Anita. 2008. Cooperative Learning. Jakarta: Grasindo

[18] Rusman, 2012. Model-Model Pembelajaran. Jakarta: Rajawali Press Sanjaya, Wina, 2006. StrategiPembelajaran. Jakarta: Kencana

[19] Sanjaya, Wina. 2010. Kurikulum Dan Pembelajaran. Jakarta: Prenada Media Group

[20] SitiCholifatul Indah. 2015. Pengaruh Model Pembelajaran Discovery Learning TerhadapKeaktifan Dan HasilBelajarMatematikaSiswaKelas Viii MtsnKarangrejo. Skripsi (Institut Agama Islam NegeriTulungagung)

[21] Sudirman A.M, 2008. Interaksi\&MotivasiBelajarMengajar

[22] Suprijono, Agus. 2012, Cooperatif Learning: TeoridanAplikasi, Yogyakarta:PustakaPelajar.

[23] Suryosubroto. 2002. Proses BelajarMengajar di Sekolah. Jakarta: RinekaCipta.

[24] Wahab. 2013. Penggunaan Model PembelajaranTalking ChipsUntukMeningkatkanHasilBelajarSiswaPadaKonsepAlatTubuhMak hlukHidup Dan Fungsinya. Skripsi (Universitas Islam NegeriSyarifHidayatullah Jakarta

[25] Widiarty. Z, 2013. Pengaruh model pembelajarankooperatifTipekancinggemerincingterhadaphasil Dan minatbelajarmatematikasiswaKelas vii smpdwisejahteraPekanbaru. Skripsi (Universitas Islam Negeri Sultan SyarifKasyi Riau). 